\title{
Wall and partition products for low-rise buildings on the basis of gypsum with environmentally friendly natural filler
}

\author{
Mariya Safonova ${ }^{1}$, Aitalina Syromyatnikova ${ }^{2}$, Nurguyana Ammosova, ${ }^{1, *}$, and Kira \\ Filippova $^{1}$ \\ ${ }^{1}$ M.K. Ammosov North-Eastern Federal University, Belinsky 58, Yakutsk, 677000, Russian \\ Federation \\ ${ }^{2}$ Larionov Institute of the Physical-Technical Problems of the North of the Siberian Branch of the \\ RAS, Oktyabrskaya 1, Yakutsk, 677890, Russian Federation
}

\begin{abstract}
The possibility of using horsehair in gypsum-based wall and partition products as a reinforcing additive has been investigated. It was established that the magnitude of the pressing pressure has a significant effect on the strength of the material.
\end{abstract}

\section{Introduction}

The urgent task of modern construction is the need to increase the production of environmentally friendly building materials, among which gypsum binders and products based on them, which are characterized by good fire resistance, soundproofing ability, hygiene, wide range of strength characteristics and low thermal conductivity [1-6], occupy a worthy place. The proportion of materials of gypsum binders in technically developed countries reaches $20-27 \%$ of the total volume of products made from mineral binders. The most promising plaster finishing materials are gypsum and gypsum sheets [7-9].

Compared to other materials (brick, reinforced concrete) gypsum wall products are distinguished by the smallest mass, for example, the weight of one square meter of housing made of brick is 2.5 tons, that for reinforced concrete is 2 tons, and for gypsum, with reference to one or two-storey residential houses with bearing walls of gypsum blocks - less than a ton. However, over the past decades, the production of gypsum building materials and products has been developing at low rates despite some growth in the consumption of gypsum finishing materials in recent years [10-15].

Gypsum-fiber materials are made from building gypsum reinforced with dissolved pulp waste paper and various technological additives [16-19]. Due to the cellulose fiber, which plays the role of a reinforcing element, such materials are characterized by increased strength and hardness, however, compared with drywall, they are less flexural, not so adapted for plastics in the process of interior finishing and are difficult to process.

\footnotetext{
*Corresponding author: nurguyanaammosova@mail.ru
} 
The possibilities of gypsum binders, in our opinion, are far from exhausted and can be implemented at a qualitatively different level. Their widespread introduction into the practice of construction could be not only one of the ways to solve the problem of cement deficiency, but also save energy resources, increase the economic efficiency of binders, and create lowenergy technologies for their production. Therefore, the urgent task is creation of composite materials based on gypsum with a rational composition of environmentally friendly fillers of natural origin and the improvement of their performance characteristics.

The aim of this work is to develop a method for obtaining wall materials and partition products for low-rise buildings based on gypsum with environmentally friendly natural horsetail filler and to study its impact on the strength characteristics.

In our studies, an additive of natural origin, horsehair, was used as a reinforcing component in the gypsum binder. The choice is based on the fact that this material has a unique complex of physical-mechanical properties, which is due to its structural features the presence of a dense cortical layer with a developed relief and a loose core, it is environmentally friendly and can be obtained from production waste.

Horsehair $(\mathrm{HH})$ has a high level of strength and plastic properties. Tensile strength of $\mathrm{HH}$ is about $600 \mathrm{MPa}$, which is comparable with the tensile strength of a steel wire. HH also has a high extensibility, with the highest values of the characteristics observed in the hair from the tail (Table 1).

Table 1. Tensile strength of horsehair (in \% to the initial length)

\begin{tabular}{|l|c|c|c|c|c|c|}
\hline \multirow{2}{*}{ Hair category } & \multicolumn{2}{|c|}{ Total elongation } & \multicolumn{2}{c|}{ Residual elongation } & \multicolumn{2}{c|}{ Elastic elongation } \\
\cline { 2 - 7 } & $\begin{array}{c}\text { Average } \\
\text { value }\end{array}$ & $\begin{array}{c}\text { In the } \\
\text { range }\end{array}$ & $\begin{array}{c}\text { Average } \\
\text { value }\end{array}$ & $\begin{array}{c}\text { In the } \\
\text { range }\end{array}$ & $\begin{array}{c}\text { Average } \\
\text { value }\end{array}$ & $\begin{array}{c}\text { In the } \\
\text { range }\end{array}$ \\
\hline Tail & 81 & $47-69$ & 32 & $15-45$ & 29 & $15-35$ \\
\hline Juba & 42 & $36-53$ & 22 & $15-31$ & 20 & $15-24$ \\
\hline Forelock & 36 & $19-50$ & 17 & $14-23$ & 19 & $12-30$ \\
\hline
\end{tabular}

\section{Materials and methods}

As a binder, we used a gypsum binder of the G-5 grade, produced by Volma LLC, Volgograd; a reinforcing agent was horsehair fiber from a tail of 5,10,15 mm length. The consumption of $\mathrm{HH}$ for all compositions was $0.42 \%$ by weight of the binder, the normal density was $55 \%$. The HHs were evenly distributed in the gypsum dough until a homogeneous mixture was formed, from which standard samples were made: square prisms of $160 \times 40 \times 40 \mathrm{~mm}$ (Fig. 1). 


\section{EECE-2018}
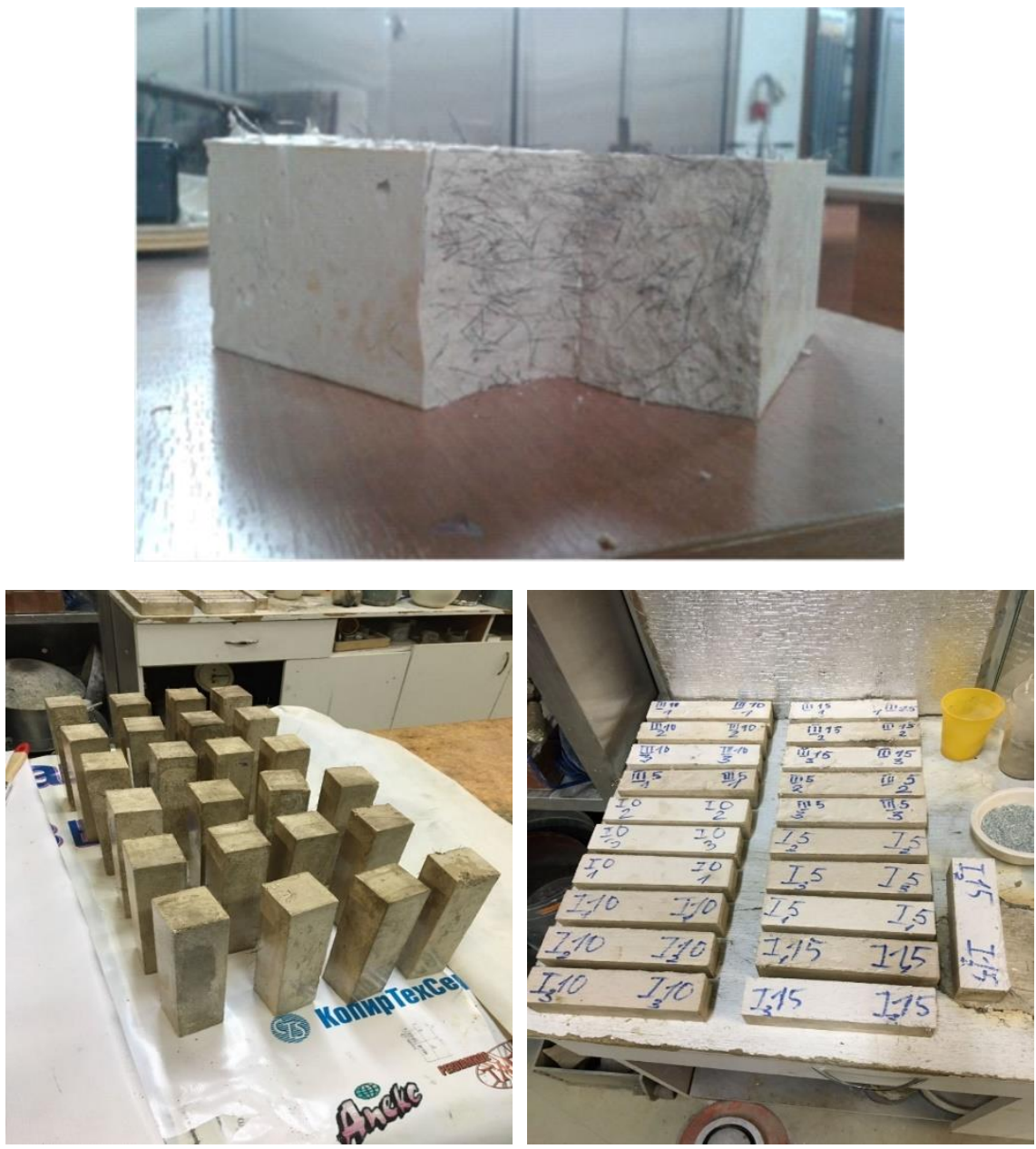

Fig. 1. Wall and partitioning products on the basis of gypsum with a reinforcing agent - horsehair fibers from a tail of 5, 10, $15 \mathrm{~mm}$ length.

Tests for durability at bending and for durability at compression were carried out by means of the IP-1250-m test press according to GOST 23789-79. Structural studies were performed using the JEOL JSM-6480LV scanning electron microscope. HH samples for structural studies were washed with warm water and soap, then with $10 \%$ acetic acid solution. After the samples were degreased by ethanol: diethyl ether mixture of the ratio $1: 1$, dried at room temperature on filtered paper and fixed on aluminum tables with conductive glue.

In our previous studies, it was shown that the introduction of a fiber hair-reinforcing additive in the form of horsehair into a gypsum bond leads to an increase in the tensile strength both in bending and compression in the entire range of the studied fiber lengths ( 5 $15 \mathrm{~mm}$ ), and the best characteristics are achieved at the maximum length of the fibers. Also it leads to the improvement of the thermal insulation properties of the composite material, which is associated with high level of physical and mechanical properties of the used filler and its structural features [20].

The data on the influence of pressing mode on the strength of the obtained material are presented in Figure 2. 


\section{EECE-2018}

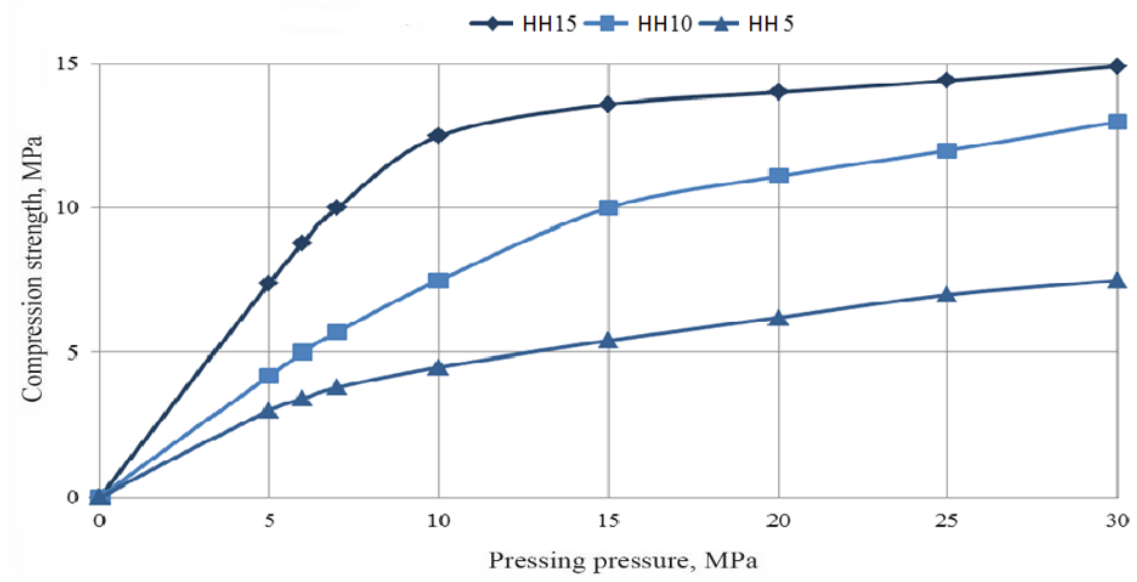

Fig. 2. Relation between compression strength of the samples and pressing pressure for various contents of raw mixtures

With increasing pressing pressure, the strength of the samples increases. At the same time, a noticeable increase in strength is observed at pressing pressures up to $10-15 \mathrm{MPa}$, further the increase in strength is less significant. So, pressing of gypsum compositions is recommended at pressures in the range of 15-20 MPa. Strength characteristics of the gypsum material are improved: introduction of a reinforcing agent leads to an increase in tensile strength both in bending and in compression, with the best values being achieved for $\mathrm{HH}$ length of $15 \mathrm{~mm}$. (Fig. 2).

Table 2. Compression strength characteristics of the samples expressed in MPa

\begin{tabular}{|c|c|c|c|}
\hline \multirow{2}{*}{ Characteristics } & \multicolumn{3}{|c|}{ HH length, mm } \\
\cline { 2 - 4 } & 15 & 10 & 5 \\
\hline Pressing pressure, $\mathrm{MPa}$ & & & 3 \\
\hline 5 & 7.4 & 5 & 4.2 \\
\hline 10 & 12.2 & 7.5 & 5.4 \\
\hline 15 & 13.6 & 10 & 6.2 \\
\hline 20 & 14 & 11.1 & 7 \\
\hline 25 & 14.4 & 12 & \\
\hline 30 & 14.9 & 13 & 4.6 \\
\hline Holding time, min & & & 5.4 \\
\hline 0.5 & 11.9 & 9 & 5.7 \\
\hline 1 & 14.3 & 10.8 & 6 \\
\hline 1.5 & 14.9 & 11.2 & 11.5 \\
\hline 2 & 16 & &
\end{tabular}

Basing on the fact that presses for making compositions have different capacities (pressing time - from 6 to $30 \mathrm{~s}$ ), the influence of pressing times of samples on their strength was investigated (Fig. 3). Samples of the same composition were kept under pressure from 5 $\mathrm{s}$ to $5 \mathrm{~min}$ and held for 5 days. 


\section{EECE-2018}

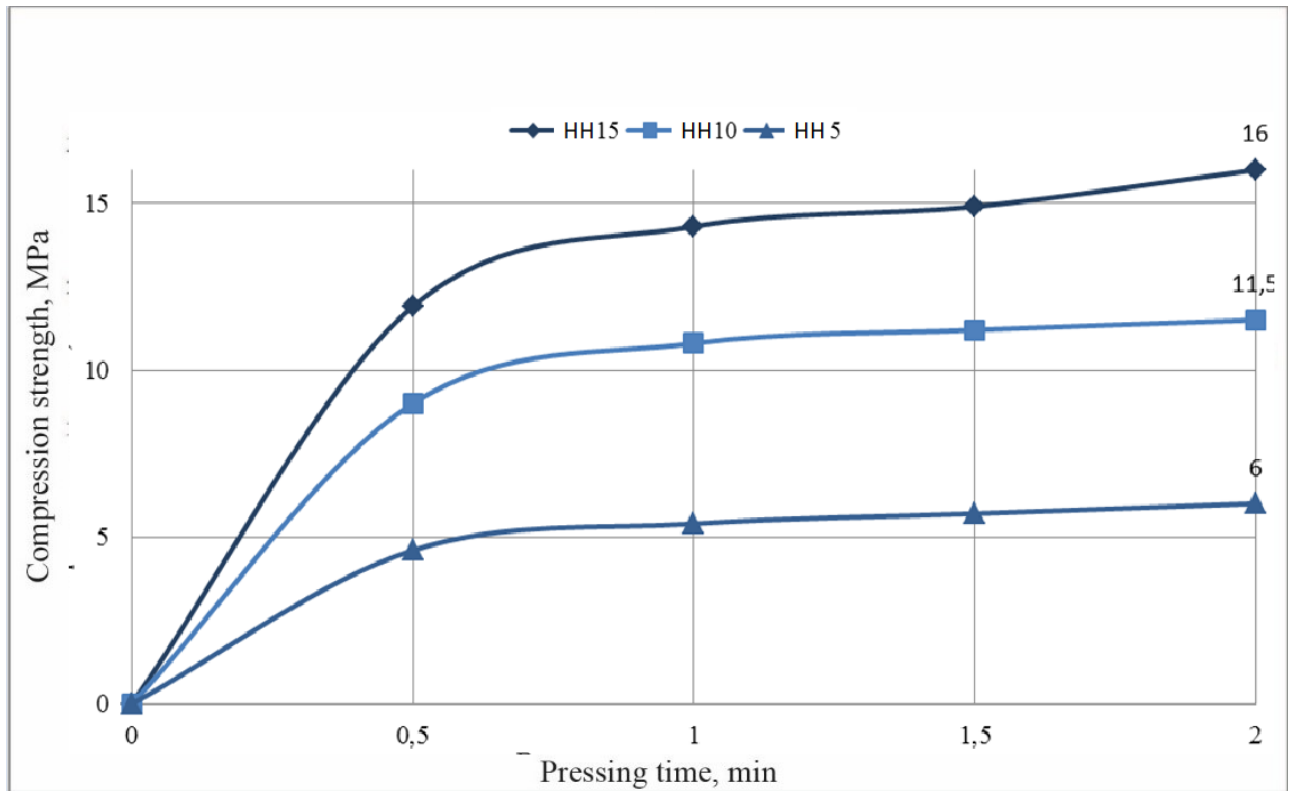

Fig. 3. Relation between compression strength and pressing time

It was established that the time of pressing the mixture more than 2 minutes does not affect the strength characteristics of the material and the bulk density of the samples of the compositions. The maximum impact of the exposing time on the strength of the samples is achieved at low specific pressing pressures (Table 2).

\section{Results and discussion}

The shape of a horsehair is spindle-shaped, the cuticle is tape-like along the whole length of the stem, the cortical layer is dense, the cross-sectional shape is round, the hair is about 150 microns thick (Fig. 3). 


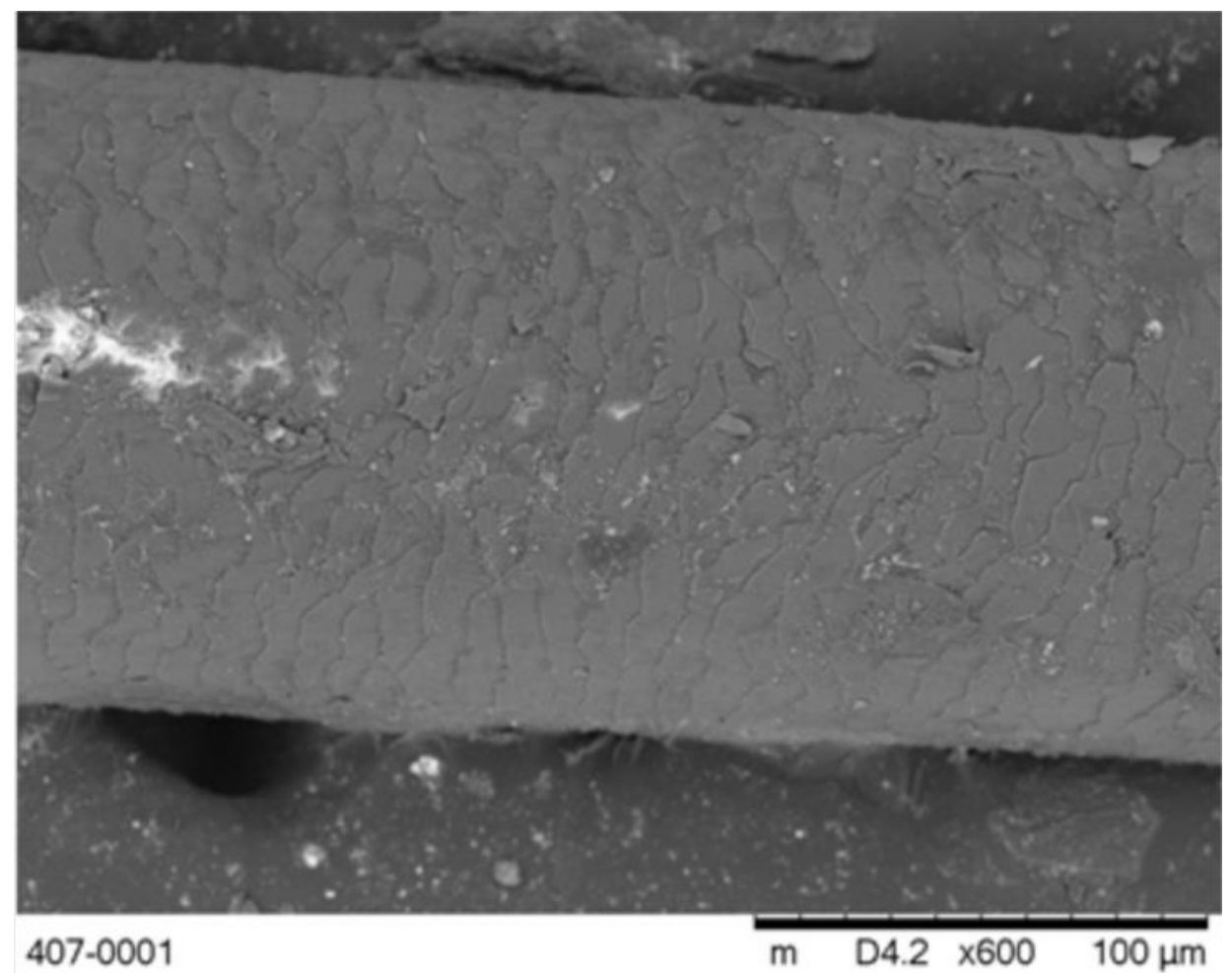

Fig. 4. SEM image of the horsehair

The introduction of the filler positively affects the change in the density and porosity of the gypsum material (Fig. 5). This can be explained by the unique properties of horsehair, which, due to the developed surface of the cortical layer and loose core, is able to accumulate air from the surrounding pores. 


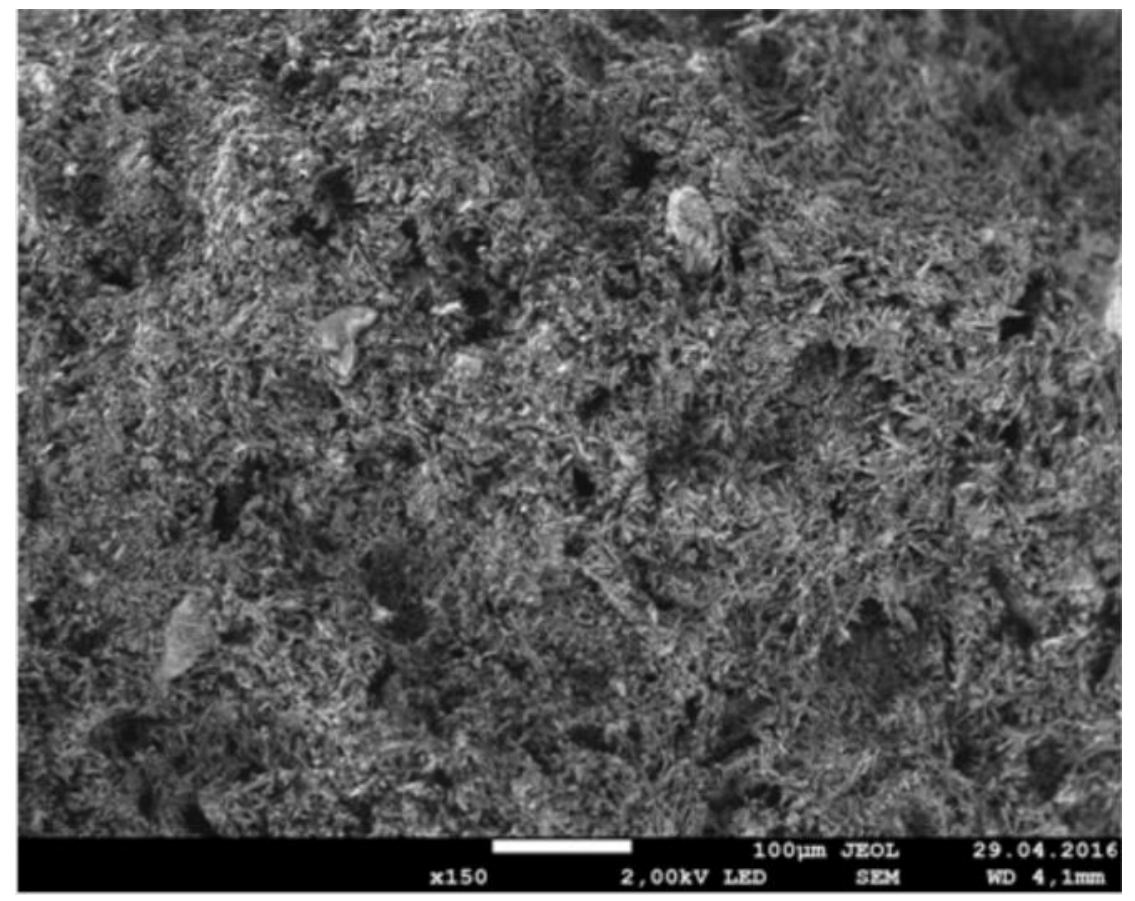

Fig. 5. SEM image of the bend of gypsum material with reinforcing additive

With increasing of pressing pressure we observed decrease of the material porosity. With pressing pressure decrease from 5 to $20 \mathrm{MPa}$, the porosity decreases for $9-14 \%$ (Fig.6)

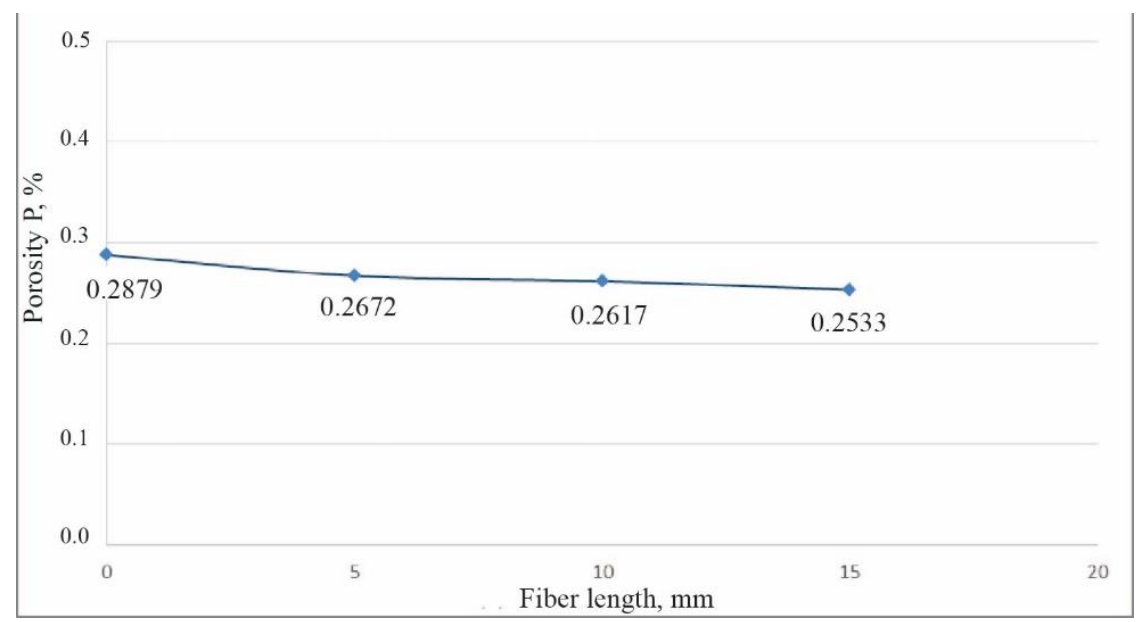

a) 


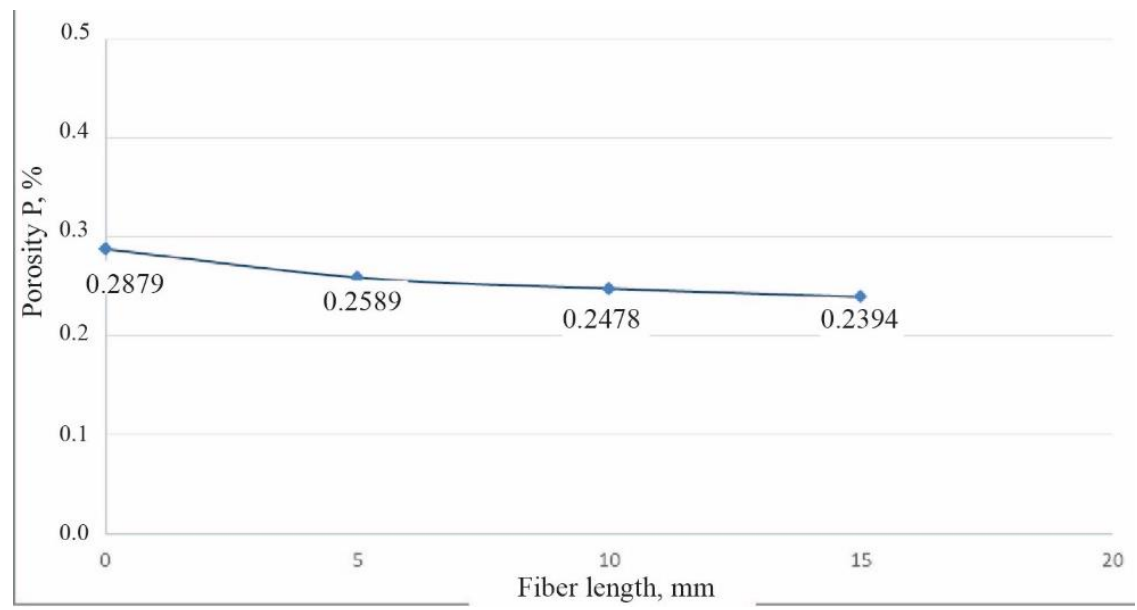

b)

Fig. 6. Relation between porosity and fiber length: a) at pressure $10 \mathrm{MPa}, \mathrm{b}$ ) at pressure $20 \mathrm{MPa}$

\section{Conclusions}

1. It has been established that the value of the pressing pressure has a significant effect on the strength of the material - a noticeable increase in strength is observed at pressing pressures up to 10-15 MPa, further the growth of strength is less significant. So pressing of gypsum compositions is recommended to be carried out at pressures in the range of 15-20 MPa. With an increase of the pressing pressure, a decrease in the porosity of the material is observed (with a change in the pressing pressure from 5 to $20 \mathrm{MPa}$, the porosity decreases by $9-14 \%$ ). Also it was found that an increase in pressing time has a positive effect on the strength of the material, especially at low pressing pressures.

2. On the basis of the conducted studies, it was revealed that introduction of a fibrous reinforcing additive in the form of horsehair into the gypsum bond leads to an increase in the tensile strength both during bending and compression in the whole range of the studied fiber lengths $(5-15 \mathrm{~mm})$ with a maximum fiber length.

3. The possibility of using natural fiber material from horsehair in wall materials based on gypsum as a reinforcing additive is shown, which makes it possible to expand the range of building materials with improved strength characteristics and environmental safety.

\section{References}

1. A. Fedulov Zhilishchnoe stroitel'stvo, 1, 3-7 (2008)

2. A. Luk'yanova, I. Starostina. Fundamental'nye issledovaniya, 4-4, 818-822 (2013)

3. A. Gajfullin, M. Haliullin, R. Rahimov. Stroitel'nye materialy, 7, 28 -32 (2014)

4. B. Rumyancev, A. Fedulov. Stroitel'nye materialy, 1, 22-25 (2006)

5. V. Strokova Stroitel'nye materialy, 7, 9-11 (2012)

6. V. Strokova, A. Sumin, V. Nelyubova, N. Shapovalov. Vestnik BGTU im. V.G. Shuhova, 3, 36-39 (2015)

7. V. Korovyakov, A. Bur'nov, Zhilishchnoe stroitel'stvo, 12, 38-40 (2015)

8. G. Solopova. Molodoj uchenyj, 3, 356-357 (2014)

9. O.Voloshina Cement. Beton. Suhie smesi, 1, 84-93 (2012) 
10. Yu. Tokarev, E. Ginchickij, Yu. Ginchickaya, A. Gordina, G. Yakovlev. Stroitel'nye materialy, 1-2, 84-89 (2016)

11. O. Gain, A. Pichugin, V. Hritankov. Polzunovskij vestnik, 1, 53-55. (2014)

12. G. Yakovlev, I. Polyanskih, Yu. Tokarev, A. Gordina. Aktual'nye problemy sovremennoj nauki, tekhniki i obrazovaniya, 2(1), 203-206 (2013)

13. Yu. Tokarev, E. Ginchickij, G. Yakovlev, A. Bur'yanov, Stroitel'nye materialy, 6, 8487 (2015)

14. V. Petropavlovskaya, V. Belov, T. Novichenkova. Tverskoj gosudarstvennyj tekhnicheskij universitet, 1, 36-37 (2014)

15. G. Zimakova, E. Kasper, O. Bochkareva, Mezhdunarodnyj zhurnal ehksperimental'nogo obrazovaniya, 3-2, 222-223 (2015)

16. E. Buldyzhova, N. Gal'ceva, A. Bur'yanov, V. Petropavlovskaya, Aktual'nye problemy sovremennoj nauki, tekhniki i obrazovaniya, 2(71), 197-200 (2013)

17. N. Chernysheva, M. Drebezgova, E. Glagolev, Vestnik BGTU im. V.G. Shuhova, 1(10), 37-44 (2016)

18. N. Chernysheva, Promyshlennoe i grazhdanskoe stroitel'stvo, 8, 57-60 (2014)

19. N. Chernysheva, M. Drebezgova, Suhie stroitel'nye smesi, 3, 1-21 (2015)

20. M. Safonova, A. Syromyatnikova, N. Ammosova, K. Filippova, P.Tarasov, A.Malyshev, O. Kravcova, S.Tihonova. Materialovedenie, 8, 34-37 (2018) 